\title{
MENINĖS GIMNASTIKOS SPORTININKIŲ VARŽYBŲ LAIKOTARPIO RENGIMO IR PARENGTUMO SĄVEIKA
}

\author{
Renata Rutkauskaitè \\ Lietuvos kūno kultūros akademija, Kaunas, Lietuva
}

\begin{abstract}
Renata Rutkauskaitè. Lietuvos kūno kultūros akademijos edukologijos krypties doktorantè. Mokslinių tyrimų kryptis — sportininkų rengimo
\end{abstract} optimizavimas.

\begin{abstract}
SANTRAUKA
Meninès gimnastikos atstoviu sportinès specializacijos etapu didèja krūviai, o kartu su jais didejja ir sportininkiu funkcinio, techninio bei atletinio parengtumo reikalavimai. Nuolat augant sudètingos koordinacijos šaku sportininku rengimo krūviams, kyla klausimas, koks krūvis turètu büti optimalus. Meninès gimnastikos krūviu ir sportinio parengtumo sqveika yra neanalizuota. Tyrimas atliktas nagrinejjant penkiu Kauno gimnastikos sporto mokyklos varžybu laikotarpio rengimo programu veiksminguma, kuris buvo nustatomas stebint 25 gimnasčiu (po 5 kiekvienoje rengimo programoje) sportinius rezultatus. Nustatyta, kad per 24 savaičiu varžybu laikotarpi sportininkès atliko 183 -309 valandu krūvi. Veiksmingose rengimo programose taikyti optimalieji krūviai (po 239 ir 270 h). Veiksminguma neigiamai paveike ir per dideli, ir per maži krūviai. Veiksmingose rengimo programose dominavo du rengimo komponentai: varžybiniu pratimu (31,26\%) (Медведева, 2001, 2002; Martin et al., 1991) ir atskiru elementu (30,13\%) tobulinimas. Varžybiniu pratimu tobulinimas dominavo ir mažiausiai veiksmingose rengimo programose (32,55 ir 34,39\%). Lyginant su parengiamuoju laikotarpiu (Rutkauskaitè, Skarbalius, 2003), sumažejo choreografijai skirtas laikas veiksmingose rengimo programose (nuo $31 \mathrm{iki} 26 \%$ ). Koreliacine analize $(r=-0,48, r=-0,83, r=-0,73, r=-0,66)$ parode, kad daugelyje rengimo programu techninio rengimo rūšys (varžybiniu pratimu ir atskiru elementu tobulinimas) kompensavo viena kita. Neigiama techninio rengimo rūšiu ir fizinio rengimo koreliacija patvirtina teigini, kad atliekant varžybinius pratimus savaime didejja šio amžiaus gimnasčiu fizinio rengimo krūviai. Nagrinètose rengimo programose nustatyti du krūvio kilimo momentai per varžybu mikrocikla (savaitès 2-a ir 5-a diena). Varžybu mikrociklo metu nustatyta antroji krūviu kilimo banga leido suformuluoti kita mokslinę problema: ar pakanka 24 valandu sportininkei visiškai atsigauti po intensyviu treniruočiu krūviu, kad būtu pasiekti geriausi sportiniai rezultatai varžybu metu.
\end{abstract}

Raktažodžiai: meniné gimnastika, varžybu laikotarpis, sportininku rengimas ir parengtumas.

\section{IVADAS}

$\mathrm{S}$ portininku rezultatai (veiksmingas rengimas) priklauso nuo kryptingo rengimo visais daugiamečio rengimo etapais (Harre, 1982; Платонов, 1986, 1997; Martin et al., 1991; Bompa, 1999). Kiekvieno rengimo etapu reikia atsižvelgti į taikomus krūvius, sportininko atsaką i krūvius, norint pasiekti geriausią to laikotarpio rezultatą (Bompa, 1999; Karoblis, 1999, 2001; Mester, Perl, 2000, 2001). Tokia rengimo ir parengtumo sąveika įvardijama kaip sportininku rengimo metamodelis (Mester, Perl, 2000).

Sudètingos koordinacijos rungčiu sportininkams visą laiką buvo taikomi dideliu apimčiu intensyvūs krūviai. Tokia tendencija atsirado dèl vis sudètingesnès meninès gimnastikos varžybinès veiklos ir didejjančios konkurencijos (Чедураев, 1997; Eider, 1999; Knoll et al., 2000). Sportinès specializacijos etapo pabaigoje (Лисицкая и др., 1982; Jastrjembskaia, Titov, 1999) augantys varžybų programos reikalavimai, varžybų skaičius per metus kelia labai didelius sportininkès funkcinio, techninio ir fizinio parengtumo reikalavimus (Каледина, 1999; Douda et al., 2000, 2004; Полищук, 2001). Ypač dideli krūviai gimnastems tenka per varžybų laikotarpi. Iškyla problema, kaip derinti treniruotès krūvị ir turini, kad viso sezono 
metu būtų išlaikomas geras sportinis parengtumas, o svarbiausiose varžybose pasiekiami geriausi rezultatai.

Straipsnyje nagrinejjamo varžybų laikotarpio fizinio, techninio, taktinio rengimo procentinè struktūra leistų parengti meninès gimnastikos rungties modeli, kuris sudarytų palankias prielaidas sportininkui siekti geriausių rezultatu (Giulio et al., 2002; Савич, 2002). Nustatoma, kuri rengimo programa veiksmingiausia ir geriausiai padètu tobulinti sportininkių rengimą.

Tyrimo tikslas - išanalizuoti ir nustatyti $11-12$ metu amžiaus meninès gimnastikos atstovių sportinès specializacijos rengimo etapu taikomų varžybų laikotarpio rengimo programų ir parengtumo sąveikos ypatumus.

Tyrimo objektas - meninès gimnastikos sportininkių rengimas ir parengtumas.

\section{Uždaviniai:}

1. Nustatyti veiksmingiausią rengimo programą.

2. Nustatyti gimnasčių rengimo krūvių ir parengtumo (rezultatu) sąveiką.

\section{Tyrimo metodai:}

1. Literatūros šaltinių analizè.

2. Dokumentų analizè (krūvių registravimo protokolas, varžybų protokolų analizė: Rengimo programų veiksmingumas nustatytas taškų rangavimo būdu mažèjančia tvarka).

3. Matematinè statistika: procentinių reikšmių vidurkiai ir standartiniai nuokrypiai palyginti dviejų veiksnių dispersine analize, ryšys tarp kiekybinių dydžių vertintas koreliacijos koeficientu $r$.

Tyrimo organizavimas. Varžybų laikotarpiu nuo 2003 metu sausio iki birželio mènesio pabaigos buvo tirtos Kauno gimnastikos sporto mokyklos meninès gimnastikos sportininkių $(\mathrm{n}=25)$ penkios rengimo programos (3 lent.). Kiekvienoje grupeje buvo 5 tiriamosios. Krūvių registravimo protokoluose, kurie parengti remiantis literatūros šaltinių analize (Лисицкая и др., 1982; Jastrjembskaia, Titov, 1999), buvo registruojamas kiekvienos treniruotès choreografijai, atskiriems elementams, varžybiniams pratimams ir fiziniam rengimui skirtas laikas (Rutkauskaite, Skarbalius, 2003).

\section{REZULTATAI}

Remiantis sportininkių varžybų rezultatais (daugiakovès užimtomis vietomis) nustatyta, kad veiksmingiausia buvo B rengimo programa
(208 tšk.), kurioje vyravo varžybinių pratimų atlikimas $(31,26 \%)$ (1 pav.). Kitos gimnastès, kurių rengimo programose (A ir D) taip pat vyravo varžybinių pratimų atlikimas $(32,55$ ir $34,39 \%$ atitinkamai), varžybose pasirodè nesèkmingiausiai (379 ir 309 taško; $75,8 \pm 18$ ir $61 \pm 25,1$ ). Sportininkių, kurių rengimo programoje vyravo atskirų elementų tobulinimas (C, E programos), varžybose pasirode vidutiniškai.

Sportininkès treniravosi pagal skirtingas programas (1 lent.) — reikšmingai skyrèsi taikomų krūvių $(\mathrm{p}<0,001)$ ir treniruočių dienų rodikliai. Varžybu skaičiaus ribos pateiktos remiantis kiekvienos rengimo programos visu 5 gimnasčiu varžybine patirtimi. Treniruočių valandų skaičius (B rengimo programa $-269,66$ h) akivaizdžiai lèmé sportinius rezultatus (1 vieta), tačiau per dideli krūviai (D rengimo programa - 309,42 h) galejo ir neigiamai paveikti veiksmingumą (4 vieta).

Skirtingu mikrociklų treniruočių krūviai pateikti 2 lenteleje. Nustatyti patikimi $(\mathrm{p}<0,05)$ taikomų mikrociklų krūvių skirtumai: tarp varžybų ir ugdomojo (A, B ir D rengimo programose), tarp ugdomojo ir atgaunamojo (A), akcentuotojo ir varžybų (C ir D), akcentuotojo ir atgaunamojo (C), varžybu ir atgaunamojo (D). E rengimo programoje taikytų krūvių patikimi skirtumai nenustatyti per visus mikrociklus.

Veiksmingiausiose rengimo programose dominavo skirtingos rengimo dalys: B - varžybinių pratimų tobulinimas ir $\mathrm{C}$ atskirų elementu tobulinimui skirtas laikas. Mažiausiai veiksmingose rengimo programose (A ir D) taip pat dominavo varžybinių pratimų atlikimas (3 lent.). Varžybiniams pratimams skirtas laikas visose programose labai varijavo (palyginus standartinio nuokrypio reikšmes - nuo 7,56 iki $11,0 \%$ ) priklausomai nuo mikrociklo tipo.

Nustatyti varžybų mikrociklų krūvių procentinès struktūros skirtumai (2 pav.). Visose programose (išskyrus $\mathrm{C}-23,3 \%$ ) daugiausia laiko buvo skiriama varžybinių pratimų atlikimo tobulinimui (nuo 30,8-36,6\%). Lyginant varžybu mikrociklą su kitais, mažiausia dèmesio jame buvo skiriama fiziniam rengimui: nuo 10,6 (D) iki 20,3\% (C).

Per atgaunamaji mikrociklą veiksmingose rengimo programose didžiausias dèmesys buvo skiriamas techniniam rengimui: choreografiniam (B - 30,46\%) ir atskirų elementų tobulinimui $(\mathrm{C}-35,0 \%, \mathrm{E}-34,2 \%)$. Mažiausiai veiks- 


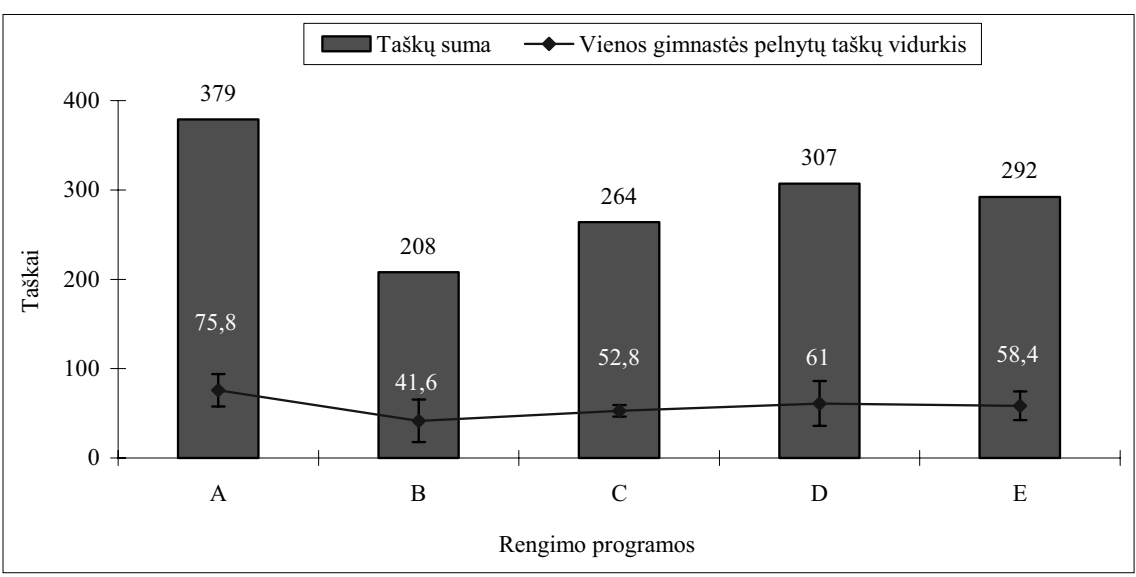

1 pav. Meninès gimnastikos sportininkių pelnyti daugiakovės taškai ir vienos gimnastès taškų vidurkis ( $\bar{X} \pm \mathrm{SD})$

\begin{tabular}{|l|c|c|c|c|}
\hline \multirow{2}{*}{$\begin{array}{c}\text { Rengimo } \\
\text { programos }\end{array}$} & $\begin{array}{c}\text { Iš viso per 24 } \\
\text { savaites, } \mathrm{h}\end{array}$ & $\begin{array}{c}\text { Per savaitę, } \\
\mathrm{h} \pm \mathrm{SD}\end{array}$ & $\begin{array}{c}\text { Darbo dienos per } \\
\text { savaitę, kartai }\end{array}$ & $\begin{array}{c}\text { Vienos gimnastès } \\
\text { varžybų skaičius, kartai }\end{array}$ \\
\cline { 2 - 5 } $\mathrm{A}$ & 183 & $7,34 \pm 0,84$ & 6,04 & $5-9$ \\
\hline $\mathrm{B}$ & 270 & $12,3 \pm 2,68$ & 5,36 & $5-10$ \\
\hline $\mathrm{C}$ & 239 & $9,56 \pm 3,11$ & 4,23 & $5-7$ \\
\hline $\mathrm{D}$ & 309 & $12,4 \pm 1,91$ & 5,46 & $3-9$ \\
\hline $\mathrm{E}$ & 191 & $7,96 \pm 1,55$ & 5,32 & $5-8$ \\
\hline
\end{tabular}

1 lentelè. Skirtingų rengimo programų krūviai, treniruočių dienų ir varžybų skaičius

\begin{tabular}{|c|c|c|c|c|c|c|}
\hline \multirow[b]{2}{*}{ Mikrociklai } & \multicolumn{5}{|c|}{ Rengimo programos ( $h$ / per savaitę $\overline{\mathrm{x}} \pm \mathrm{SD}$ ) } & \multirow{2}{*}{$\begin{array}{c}\text { Fišerio } \\
\text { kriterijaus } \\
\text { reikšmé } \\
\text { tarp visų } \\
\text { programų; } \\
\text { p lygmuo }\end{array}$} \\
\hline & A & B & $\mathrm{C}$ & $\mathrm{D}$ & $\mathrm{E}$ & \\
\hline Varžybų (1) & $6,58 \pm 0,95$ & $10,6 \pm 2,32$ & $10,1 \pm 2,13$ & $11,9 \pm 2,36$ & $8,04 \pm 0,97$ & $\begin{array}{l}F=11,26 \\
\mathbf{p}<\mathbf{0 , 0 0 1}\end{array}$ \\
\hline Akcentuotasis (2) & $7,45 \pm 0,4$ & $10,2 \pm 0,71$ & $9,88 \pm 0,53$ & $13,9 \pm 1,89$ & $6,75 \pm 3,18$ & $\begin{array}{l}F=5,42 \\
\mathbf{p}<\mathbf{0 , 0 5}\end{array}$ \\
\hline Ugdomasis (3) & $7,70 \pm 0,85$ & $14,25 \pm 2,11$ & $9,61 \pm 3,09$ & $12,05 \pm 1,51$ & $8,02 \pm 1,94$ & $\begin{array}{l}F=15,65 \\
\mathbf{p}<\mathbf{0 , 0 0 1}\end{array}$ \\
\hline Atgaunamasis (4) & $6,87 \pm 0,54$ & $13,44 \pm 0,31$ & 8 & $13,91 \pm 0,65$ & $8,33 \pm 1,25$ & $\begin{array}{l}F=14,31 \\
\mathbf{p}<\mathbf{0 , 0 0 1}\end{array}$ \\
\hline $\begin{array}{l}\text { Fišerio kriterijaus } \\
\text { programu; } \\
\text { p lygmuo }\end{array}$ & $\begin{array}{l}F=2,64 \\
p>0,05\end{array}$ & $\begin{array}{l}F=2,90 \\
p>0,05\end{array}$ & $\begin{array}{l}F=1,90 \\
p>0,05\end{array}$ & $\begin{array}{l}F=4,08 \\
\mathbf{p}<\mathbf{0 , 0 2 5}\end{array}$ & $\begin{array}{l}F=0,48 \\
p>0,05\end{array}$ & \\
\hline $\begin{array}{l}\text { Atskiru } \\
\text { mikrociklų } \\
\text { palyginimas } \\
\text { pagal post-hoc } \\
\text { LSD kriteriju }\end{array}$ & $\begin{array}{c}\text { tarp (1) ir (2) } \\
\mathbf{p}<\mathbf{0 , 0 5} \\
\operatorname{tarp}(3) \text { ir }(4) \\
\mathbf{p}<\mathbf{0 , 0 5}\end{array}$ & $\begin{array}{c}\operatorname{tarp}(1) \text { ir (3) } \\
\mathbf{p}<\mathbf{0 , 0 5}\end{array}$ & $\begin{array}{l}\operatorname{tarp}(2) \operatorname{ir}(3) \\
\mathbf{p}<\mathbf{0 , 0 5}\end{array}$ & $\begin{array}{c}\operatorname{tarp}(1) \text { ir }(2) \\
\mathbf{p}<\mathbf{0 , 0 5} \\
\operatorname{tarp}(1) \text { ir }(3) \\
\mathbf{p}<\mathbf{0 , 0 5} \\
\operatorname{tarp}(1) \text { ir (4) } \\
\mathbf{p}<\mathbf{0 , 0 5}\end{array}$ & - & \\
\hline
\end{tabular}

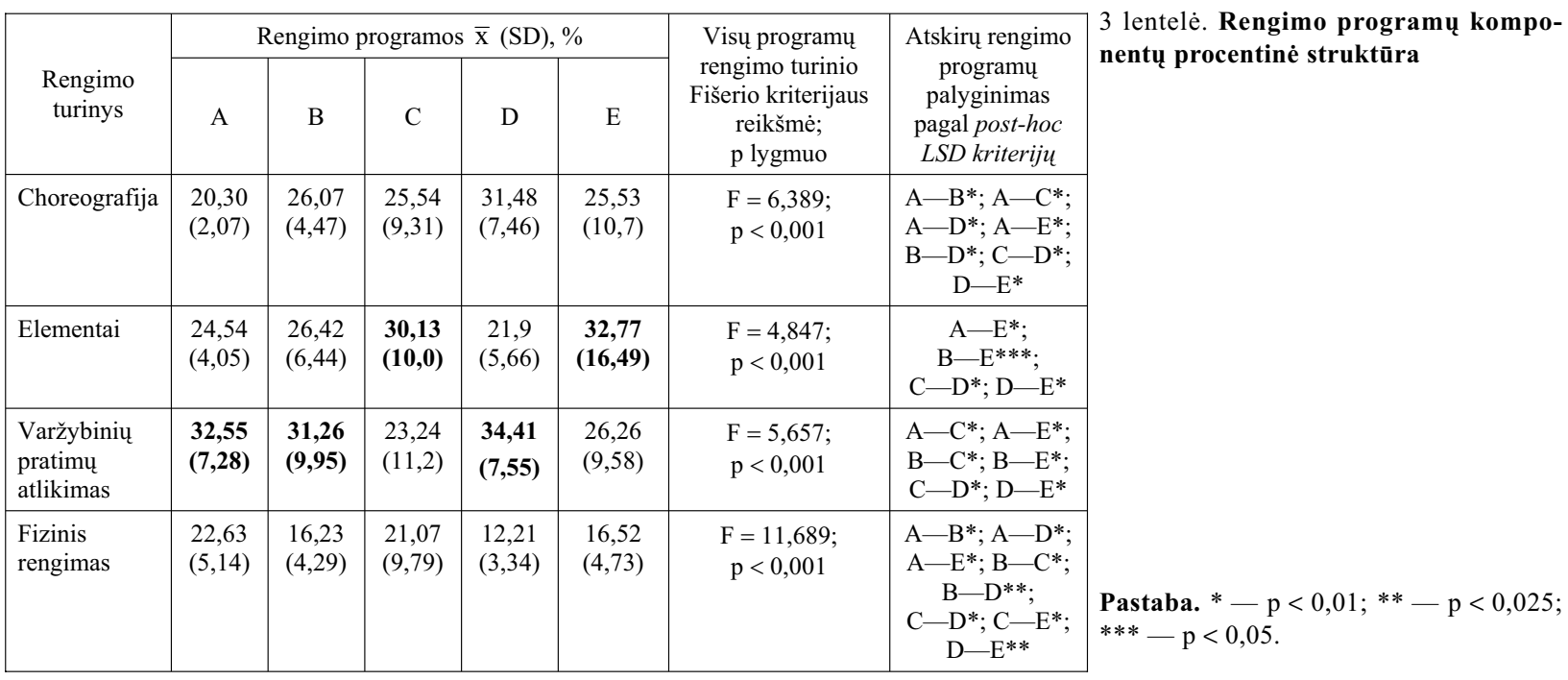


2 pav. Varžybų mikrociklo taikytų krūvių procentinè struktūra

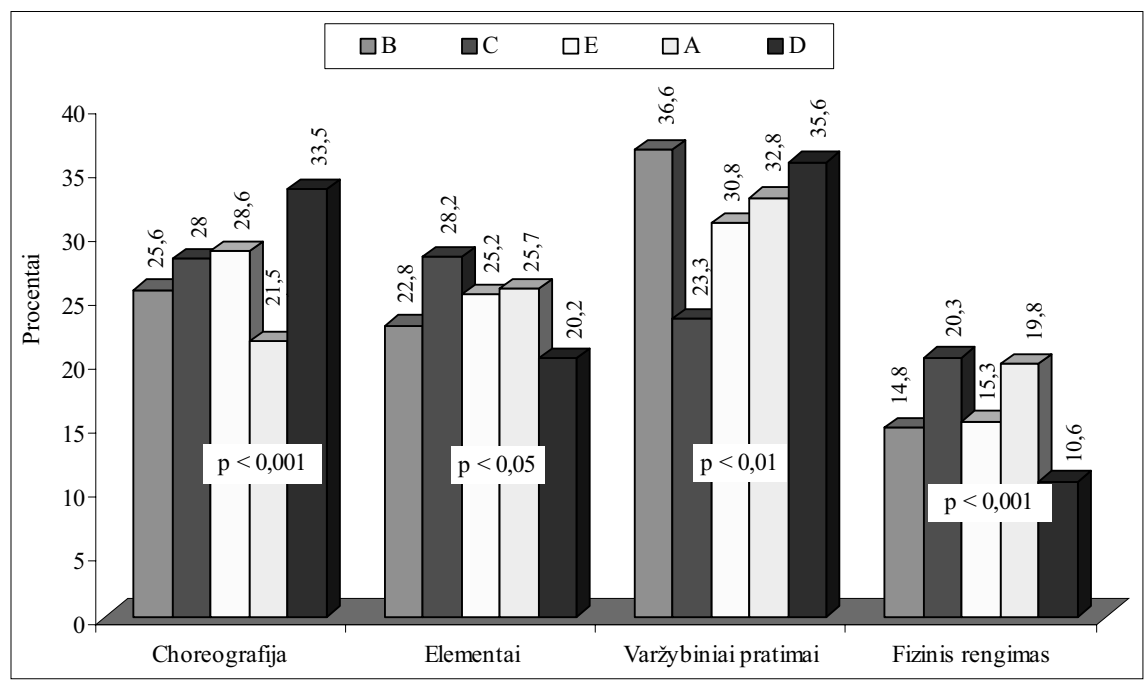

3 pav. Veiksmingiausios (B) rengimo programos varžybų mikrociklo krūvių kitimas

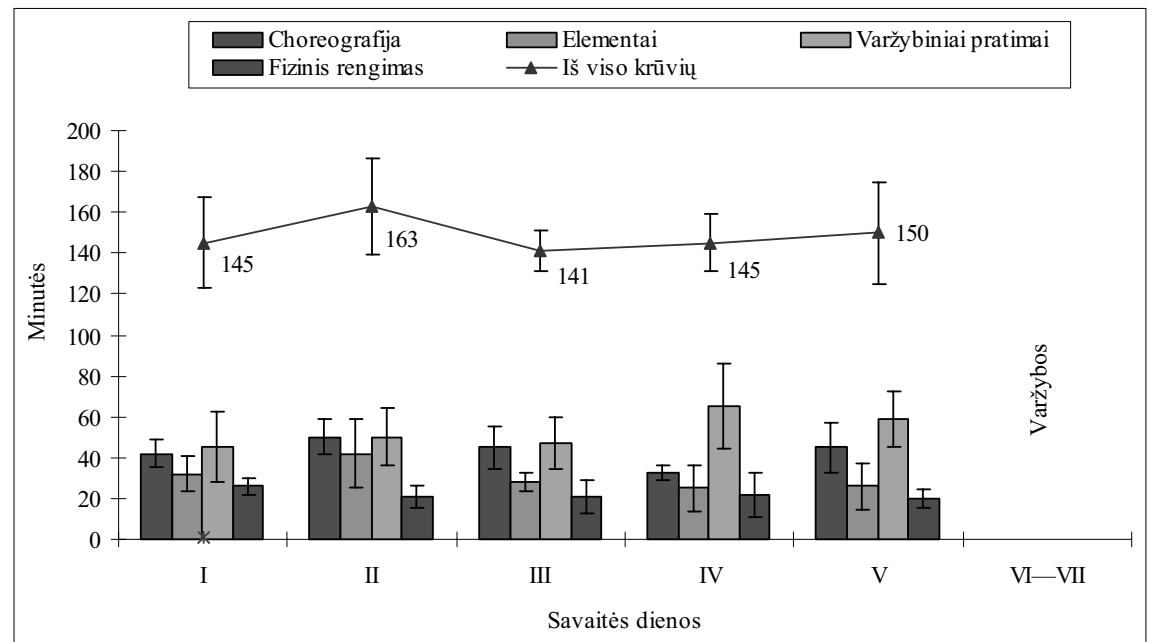

mingose programose daugiausia dèmesio skiriama fiziniam rengimui $(A-28,0 \%)$ ir varžybiniu pratimų tobulinimui $(\mathrm{D}-33,0 \%)$.

Per ugdomaji mikrociklą didžiausią dèmesi skiriant varžybinių pratimų atlikimui $(\mathrm{A}-35,9 \%$, $\mathrm{B}-31,7 \%$ ir $\mathrm{C}-35,7 \%)$ ir atskirų elementu tobulinimui $(\mathrm{C}-31,4 \%$ ir $\mathrm{E}-33,7 \%)$, labiausiai buvo lavinama specialioji ištvermè.

Antroje pagal veiksmingumą rengimo programoje nuolat (per visus mikrociklus) vyravo atskirų elementų tobulinimas. D rengimo programoje didžiausias ir nuolatinis demesys buvo skiriamas varžybinių pratimų tobulinimui (2 pav.).

Veiksmingiausios (B) rengimo programos didžiausi krūviai buvo taikyti varžybų mikrociklo antrą ir penktą savaitès dieną (3 pav.). Varžybiniams pratimams atlikti skirto laiko reikšmé buvo didesnè $(36,7 \pm 5,9 \%)$ nei vidutinè $(31,26 \pm 9,95 \%)$. Mažiau laiko skirta atskiriems elementams tobulinti $(21,1 \pm 4,8 \%)$ ir fiziniam rengimui $(15,2 \pm 1,6 \%)$.

\section{REZULTATU APTARIMAS}

Sudėtingos koordinacijos šakų sportininkų krūviai ir jų intensyvumas nuolat dideja (Чедураев, 1977; Jastrjembskaia, Titov, 1999; Knoll et al., 2000). Siekiant aukštų sportinių rezultatų, principas ,daugiau krūviu — labiau padeda“ jau nebegalioja. Irodyta, kad veiksmingas racionalus krūviu išdèstymas laiko atžvilgiu (Mester, Perl, 2000, 2001). Tai patvirtino ir mūsų tyrimo metu gauti duomenys - ne visada dideli krūviai yra veiksmingi: D rengimo programa $(309,42 \mathrm{~h})$, lyginant su B (269,66 h), buvo tik ketvirta pagal veiksmingumą. Mažiausiais krūviais rengiamų gimnasčiu programos (A -183 h ir E - 191 h) patvirtina kitų tyrèjų nuomonę (Царькова, 1980), kad pernelyg maži krūviai neleidžia parodyti visų potencinių galių.

Aktuali ne tik krūvių dydžių, bet ir rengimo turinio derinimo problema. Rengiant sudètingos koordinacijos šakų (gimnastikos, meninès 
gimnastikos, dailiojo čiuožimo) sportininkus, varžybu laikotarpiu svarbiausias dèmesys turi būti skiriamas varžybinių pratimų tobulinimui (Martin et al., 1991; Медведева, 2001, 2002), tačiau ši rengimo rūšis vyravo ne visose rengimo programose $(\mathrm{A}-32,55 \%, \mathrm{~B}-31,26 \%$, $\mathrm{D}-34,41 \%)$. Varžybų laikotarpiu smarkiai sumažèjo choreografinio rengimo dalies reikšmè veiksmingesnèse rengimo programose (B ir C: nuo 31 iki 26\%). Ankstesnio tyrimo metu nustatyta (Rutkauskaite, Skarbalius, 2003), kad parengiamuoju laikotarpiu veiksmingose rengimo programose vyravo ši rengimo dalis. S. Apatow (2001) pateikiami duomenys apie elito gimnasčiu choreografinį rengimą (po 45 minutes 6 kartus per savaitę) leidžia daryti išvadą, kad tirtu gimnasčiu choreografiniam rengimui buvo skirta per mažai laiko (vidutiniškai po 45 minutes 4 kartus per savaitę).

Parengiamojo laikotarpio techninio rengimo komponentu tarpusavio sąveika parodè, kad atskirų elementų tobulinimui ir varžybiniams pratimams skirtas laikas kompensavo vienas kitą mažiau veiksmingose rengimo programose (Rutkauskaite, Skarbalius, 2003). Nustatyta, kad ir varžybų laikotarpiu šie rengimo komponentai kompensavo vienas kita beveik visose rengimo programose (A: $r=-0,48 ; B: r=-0,8 ; D: r=-0,73$; $E: r=-0,66)$. Fiziniam rengimui skirtas laikas daugelyje programu taip pat neigiamai koreliavo su techniniu rengimu (su varžybiniu pratimu atlikimu: $\mathrm{A}: \mathrm{r}=-0,71 ; \mathrm{B}: \mathrm{r}=-0,52 ; \mathrm{C}: \mathrm{r}=-0,71$; su elementų tobulinimui skirtu laiku: $\mathrm{C}: \mathrm{r}=-0,62$; $D: r=-0,5 ; E: r=-0,59)$. Tai patvirtino anksčiau mūsų iškeltą teiginị (Rutkauskaitè, Skarbalius, 2003), kad atliekant varžybinius pratimus savaime didejja šio amžiaus gimnasčiu fizinio rengimo krūviai ir papildomai fiziniam rengimui labai daug dèmesio skirti nereikia.

Meninès gimnastikos varžybinè veikla reikalauja didelių fizinių pastangų ir energijos (Douda et al., 2000; 2004), o didejjantis varžybu skaičius reikalauja iš sportininkių pasiekti ir išlaikyti geriausią sportinę formą. Tai i̇manoma tik derinant rengimo krūvių dydžius ir intensyvumą (Mester, 1993; Mester, Perl, 2000, 2001).

Rengiant meninès gimnastikos sportininkes, dažniausiai rekomenduojamos (Аркаев, Сучилин, 1997; Jastrjembskaia, Titov, 1999) vieno mikrociklo dvi krūvių augimo bangos. Tačiau nèra pateikta medžiagos apie varžybų mikrociklo krūvių kitimą skirtingomis dienomis. Nagrinètose rengimo programose nustatyti du varžybų mikrociklo krūvio kilimo momentai (savaitès 2-ą ir 5-ą diena).

M. Kellmann (2002) teigia, kad per atgaunamaji mikrociklą rekomenduotina pakeisti pagrindinę veikla, jos pobūdị, krūviu intensyvuma ir dydị. Sportininkes rengiant didžiausiais krūviais, šio principo nebuvo laikomasi - ir per atgaunamaji mikrociklą rengimo programoje vyravo varžybiniai pratimai. Viena iš pagrindinių priežasčių, lemiančių nedidelị tirtu gimnasčiu sportini veiksmingumą, galètų būti tai, kad krūviai mažai kito skirtingo tipo mikrociklais. J. Mester (1993), T. O. Bompa (1999), P. Karoblis (1999), J. Mester ir J. Perl $(2000,2001)$ teigia, kad krūviu turinio, apimties ir intensyvumo derinimas atskirais mikrociklais yra esminè prielaida valdant sportininkų parengtumą.

\section{IŠVADOS}

1. Veiksmingiau varžybose pasirodè tos sportininkès, kurių rengimo programose vyravo varžybinių pratimų $(31,26 \%)$ ir atskirų elementų tobulinimas $(30,13 \%)$.

2. Programos veiksmingumą lèmé racionaliai taikomi rengimo krūviai: geriausius rezultatus pasiekè tos gimnastès, kurių krūviai buvo optimalūs (270 ir $239 \mathrm{~h})$. 


\section{LITERATŪRA}

Apatow, S. (2001). Why Eastern Bloc Countries Dominated the Gymnastics Field in Sydney. Prieiga per interneta: www.education.ed.ac.uk/gym/papers.sa.html

Bompa, T. O. (1999). Periodization Training for Sport. Champaign: Human Kinetics.

Douda, H., Avloniti, A., Maridaki, M., Tokmakidis, S. P. (2004). Metabolic demands of different apparatus routines between elite and sub-elite rhythmic gymnasts. 9th Annual Congress of the European College of Sport Science, 3-6 July, 320

Douda, H., Tomakidis, S. P., Nikolaidis, K. (2000). Kinanthropometric characteristics and physical fitness attributes as predictors of attainment in rhythmic sports gymnastics. Journal of Sport Sciences, Vol. 18, 7, 510.

Eider, J. (1999). Jaunujų gimnasčių specialiojo fizinio parengtumo ugdymo metodai. Sporto mokslas, 2, 3739.

Giulio, S. R., Toran, G., Fiore, A. et al. (2002). Zur Entwicklung eines Leistungsmodells im Spitzensport am Beispiel Fechten. Leistungssport, 4, 57-62.

Harre, D. (1982). Principles of Sport Training. Berlin: Sportverlag.

Jastrjembskaia, N., Titov, Y. (1999). Rhythmic Gymnastics. Champaign: Human Kinetics.

Karoblis, P. (2001). Didelio meistriškumo sportininku rengimo problemos. Sporto mokslas, 2, 2-7.

Karoblis, P. (1999). Sporto treniruotés teorija ir didaktika. Vilnius: Egalda.

Kellmann, M. (2002). Preventing Underperformance in Athletes. Human Kinetics.

Knoll, K., Knoll, K., Kothe, T. (2000). Grenzen der Leistungsfahigkeit des Menschen in den technischkompositorischen Sportarten. Leistungssport, 1, 33-38.

Martin, D., Carl, K., Lehnertz, K. (1991). Beitrage zur Lehre und Forschung im Sport. Schondorf.

Mester, J. (1993). Elite sport: The present level of scientific research - legitimation, designs and methods. Sports Sciences in Europe 1993: Current and Future Perspectives. Meyer \& Meyer Verlag. P. 245-259.

Mester, J., Perl, J. (2000). Grenzen der Anpassungs —und Leistungsfahigkeit des Menchen aus systematischer Sicht: Zeitreihenanalyse und ein informatisches Metamodell zur Untersuchung physologischer Adaptionsprozesse. Leistungssport, 1, 43-51.

Mester, J., Perl, J. (2001). Modellgestützte und statistische Analyse der Wechselwirkung zwischen Belastung und Leistung. Leistungssport, 1, 54-63.

Rutkauskaitė, R., Skarbalius, A. (2003). Meninès gimnastikos specializuotojo rengimo etapo parengiamojo laikotarpio programų veiksmingumas. Ugdymas. Kūno kultūra. Sportas, 5, 58-63.

Savchin, S., Zasada, M. (2004). Standard characteristics of training loads for elite gymnasts at the stage of maximum realization of individual capacities. Sport Training in Interdisciplinary Scientific Researches, 98-102.

Аркаев, Я. Л., Сучилин, Н. Г. (1997). Методологические основы современной системы подготовки гимнастов высшего класса. Теория и практика физической култуpbl, 11, 17-25.

Каледина, И. В., Земсков, Е. А. (1999). Особенности взаимосвязи «пулсовых режимов» и качества выполнения сложнокоординационных упражнений в художественной гимнастике: материаль конференций молодых учёных и студентов РГАФК. Москва. С. 30-37.

Лисицкая, Т. С., Бирюк, Е. В., Новик, М. Г., Батаен, В. Г. (1982). Художественая гимнастика. Москва: ФИС.

Медведева, И. М. (2001). Построение тренировочного процесса в годичном цикле подготовки. Физическое воспитание студентов творческих специильностей, 4 (сборник статей). Харьков. Prieiga per internetą: http://lib.sportedu.ru

Медведева, И. М. (2002). Построение тренировачного процесса в годичном цикле подготовки квалифицированных фигуристов. Физическое воспитание студентов творческих специальностей, 3 (сборник статей). Харьков. Prieiga per internetą: http://lib.sportedu.ru

Платонов, В. Н. (1997). Общая теория подготовки спортсменов в олимпийском спорте. Киев: Олимпийская литература.

Платонов, В. Н. (1986). Подготовка квалифицорованных спортсменов. Москва: ФИС

Полищуук, Т. (2001). Влияние на надёжностъ выполнения базовых элементов художественной гимнастики. Теория и практика физической културы, 11, 23-27.

Савич, С. (2002). Специалъная физическая подготовленность как фактор, определяющий возможности увеличения тренировочных нагрузок у юных гимнастов. Физическое воспитание студентов творческих специильностей, 7 (сборник статей). Харъков. Prieiga per interneta: http://lib.sportedu.ru

Царькова, Н. И. (1980). Управление тренировочными нагрузками спортсменок высших разрядов в художественной гимнастике. Москва.

Чедураев, В. С. (1997). Научно-методическоее обеспечение подготовки сборных команд страны по спортивной гимнастике. Теория и практика физической культуры, 11, 44-46. 


\title{
THE INTERACTION OF TRAINING AND SPORTS PERFORMANCE IN RHYTHMIC GYMNASTICS DURING COMPETITION PERIOD
}

\author{
Renata Rutkauskaitè \\ Lithuanian Academy of Physical Education, Kaunas, Lithuania
}

\begin{abstract}
In recent years, the performance programs of elite athletes in rhythmic gymnastics have become more complex (Knoll, Knoll, Kothe, 2000; Чедураев, 1997). Thus, gymnasts' long-term preparation process should be specially organized with the objective establishment of the level of sports mastery, fitness and training loads (Savchin, Zasada, 2004). No studies, which analyse rhythmic gymnastic inter-relationship between load and performance, are conducted. The aim of the research was to analyze and define $11-12$ year old (sport specialization stage) rhythmic gymnasts' interaction with load, content and performance during the competition period. Five training programs of five gymnasts' results in each group $(n=25)$ were analyzed. Subjects were the members of national and Kaunas city teams. For training contents and results' analysis training loads and performance protocols were used. Statistically significant differences $(F=26.94 ; p<0.01)$ of performed loads were in different programs. It was established that during the 24-microcycle period gymnasts performed the load of 309-183 hours. In most effective training programs different components dominated: performing competitive exercise $(31.26 \%)$ and the establishment, perfection and mastering of the new technical elements $(30.13 \%)$. This component dominated also in the less effective training programs. The effectiveness of training programs was determined by the rational using of loads (the best results had those programs in which loads were more optimal -270 and 239 hours). Higher loads (309 hours) as well as the small loads (183 hours) were less effective. In comparison with the preparatory period (Rutkauskaite, Skarbalius, 2003) the influence of choreography in most effective training programs reduced (from 31 till $26 \%$ ). Competition-like exercises and the establishment, perfection and mastering of the new technical elements were compensated by each other: this is shown by negative correlations $(r=-0.48, r=-0.8, r=-0.73$, $r=-0.66)$. Physical training negative correlation with performing competitive exercises $(r=-0.48, r=-0.8$, $\mathrm{r}=-0.73, \mathrm{r}=-0,66)$ in various programs, confirmed the previous presumption that at the age of $11-12$ years, the physical training loads increase in a natural way by introducing competition-like exercises. The research raises the problem of matching training loads and contents in the different competition microcycle during several months.
\end{abstract}

Keywords: rhythmic gymnastics, competition period, training and sports performance.

Gauta 2004 m. lapkričio 15 d.

Received on November 15, 2004

Priimta $2005 \mathrm{~m}$. birželio $30 \mathrm{~d}$

Accepted on June 30, 2005

Renata Rutkauskaite

Lietuvos kūno kultūros akademija

(Lithuanian Academy of Physical Education)

Sporto g. 6, LT-44221 Kaunas

Lietuva (Lithuania)

Tel +370 67409104

E-mail r.rutkauskaite@lkka.lt 